\title{
(Re)constructing God to find meaning in suffering: Men serving long-term sentences in Zonderwater
}

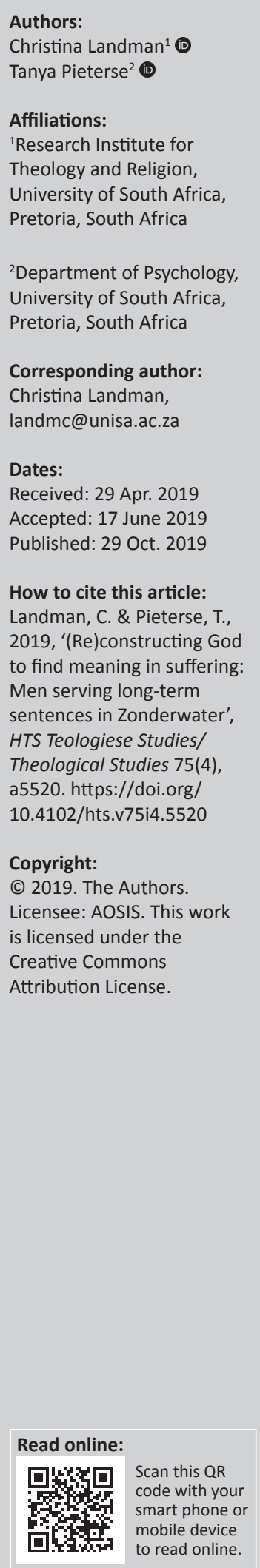

Offender populations experience their incarceration through different lenses and often as a spiritual journey of suffering. During 2017 and 2018 a study was conducted by the authors with 30 men serving long-term sentences in Correctional Centre A, Zonderwater Management Area in the Gauteng province of South Africa. Following interviews and focus group sessions, the authors report on participants' representations on how their (re)constructed views of God assist them to find meaning in suffering while incarcerated. Narrative inquiry as a philosophical framework was applied, which presupposes equality between the researcher and the participant, the unmediated representation of words as data, the researcher as autoethnographer and respectful submission to subjectivity. Participants' views of God are thematised according to sets of God-images, firstly, as identified by Van der Ven in his book God Reinvented? (1998), adapted by the authors to suit the contents of the participants' God talk. Secondly, the 'God-images in Africa' were applied. The participants' (re)constructed Godimages are divided into two categories: images that feed on the binary between divine and human (transcendence) and images that function in the dialogical spaces between divine and human where the incarcerated have internalised an external God (immanence). Binary images of God are presented by the apathetic God, retributive God, controlling God and the purifying God. However, a significant number of participants expressed their belief in God through the dialogical image of the compassionate God, and the suffering God as co-sufferer. The role of Africanness in constructing these God-images constitutes a special point of inquiry in this article, as reflected in the images of God defined by God the Great Ancestor and Divine Spirit, and God with whom a mystical union is formed.

Keywords: God-images (re)constructed; meaning in suffering; narrative inquiry; co-suffering; mystical union with God; Africanness and God.

\section{Aim of the study}

This article reports on how men serving long-term sentences at Correctional Centre A, Zonderwater Management Area (hereinafter referred to as Zonderwater), (re)construct their image of God to find meaning in and make sense of their suffering while incarcerated. The study aims to firstly describe how the participants experience and talk about God and how this God-talk has changed (or not) throughout their life journey - and now also as offender. Secondly, the aim is to explore how this (re)construction of God gives meaning to their lives while being incarcerated. Finally, the article thematises the God-images of the incarcerated participants according to the God-images identified by Johannes van der Ven in his book God Reinvented? (1998) and contextualised by the authors in a situation of incarceration. Choosing Van der Ven is based on his representation of God-images as related to the experiences of people who suffer making these images adaptable to the experiences of the offender as persons who have suffered loss, and consequently a potential loss of meaning. Additional to Van der Ven, the 'God-images in Africa' of Kasambala (2005:300) is used to focus on the role of Africanness in imaging God also in times of suffering. A narrative inquiry was applied in this study whereby the researchers are concerned with the storied lives that participants lead (Connelly \& Clandinin 1990:1) within the context of being incarcerated.

\section{Research population}

The study encompasses interviews and monthly discussion groups with 30 men serving longterm sentences (15 years or more) in the maximum-security division of Zonderwater, a correctional facility to the east of Tshwane/Pretoria, the capital of South Africa, in the Gauteng province. ${ }^{1}$ They have been sampled by the in-house psychologist and social worker according to the variables

1.The authors have previously published an article based on research with the same research population: Landman, C., Ncongwane, H.J. \& Pieterse, T., 2019, 'Men serving long-term sentences in Zonderwater Correctional Centre, South Africa: Religious identity and behavioural change', HTS Theological Studies 75(3). 
of race and religious affiliation. The racial demographics of the group of men comprise 15 black Africans, 13 whites and 2 mixed-race descent. They belong to a variety of churches and religions, with some feeling comfortable in more than one tradition. In summary, eight belong to Christian traditions, six to traditions that place a strong emphasis on the Torah, four to the Zion Christian Church (a large African Independent Church) and seven to churches that have been established in Zonderwater by the inmates themselves. Two are Muslims and two call themselves atheist, while another belongs to Brahmanism (a form of Hinduism) but does not want to be confined to a known religious affiliation.

\section{Data collection}

Data were collected during 2017/2018 using semi-structured interviews with the research population described in the previous paragraph. ${ }^{2}$ Approval to conduct the research and ethical clearance was granted by both the ethics committees of the University of South Africa and the Department of Correctional Services. Purposive sampling was applied, which does not merely rely on the random availability of a sample, but rather a particular population selected by set criteria as in this case (Terre Blanche, Durrheim \& Painter 2012:139). The sample criteria included adult male offenders who (1) were serving long-term sentences (more than 15 years) at Zonderwater, (2) have defined themselves as 'changed men' and (3) have indicated that these lifestyle changes had been affected by the irreligious beliefs and lived experiences as an offender.

Participants were informed about the aim, nature, method and process of the study and signed consent forms were obtained from all. Matters of confidentiality of all information shared and anonymity as well as their right to withdraw from the study at any stage were discussed. It was essential to inform the participants that the study had no bearing on their sentences, or impact on any parole procedures, but was solely for the purposes of research. These steps as stated by Terre Blanche et al. (2012:67-68) are essential to comply with the principles of ethical research, particularly in social sciences, such as respect for the dignity of participants, nonmaleficence, beneficence and justice.

Interviews were guided by an interview schedule. For purposes of this article, the researchers focused on how participants articulated and described their beliefs, experiences and views of God, and how their preferred image of God assisted them in finding meaning in suffering while incarcerated. After the individual interviews had been conducted, the interviewees formed a monthly discussion group where the findings of the research were discussed.

\section{Philosophical framework}

For this study, narrative inquiry as a philosophical framework was applied. This methodology is concerned with the storied lives that people lead (Connelly \& Clandinin 1990:1). Narrative inquiry focusses on human experience with a holistic quality, engaging with participants within the context of their lived world. This approach makes it most appropriate to apply in the social sciences field, in disciplines such as psychology, theology, history, literary theory, philosophy, drama and art (Connelly \& Clandinin 1990:2). In this study, we as researchers explore the offenders' lived experiences as incarcerated, and how, through their storytelling, they articulate their meaning of God. In this regard, lived experiences, stories, suffering and God are the phenomena that were studied.

By conducting narrative research, the researcher performs a dual role whereby, firstly, a very close relationship is formed between the researcher and the researched, and, secondly, the researcher operates as a responsible professional within his or her discipline and community (Josselson 2007:538). As researchers, we enter the participants' space in the middle of their stories and lives and become co-travellers on their journey. The relationship between the researcher and the researched in this method of inquiry is one of collaboration and mutual respect. We continuously negotiate our relationship with each encounter, while navigating an intentional course of actions, reminding ourselves of the research objectives, or unintentionally, by engaging alongside participants while they are living out their stories (Clandinin 2006:47).

By listening to the stories of their spiritual journeys of how they conceptualise and construct God, their words become data as we as researchers attempt to make sense of it (Clandinin 2007:13). People are continuously in a process of shaping their reality through stories of who they are and how they stand in relation to others. By interpreting their past, incorporating it into the present and how people think about their future is how they make sense of their experiences (Clandinin et al. 2015:24). In this regard, Clandinin (2007:5) emphasises that the focus is on the individual, every story told matters and the context within which they live and operate is important. This method of inquiry regards the reconstruction of the participant's lived experiences, his or her environmental context and interpersonal relations.

Working with the spoken word as researchers, we realise that there is no prescribed method of uncovering and creating meaning. It is a matter of allowing and trusting the process of journeying together with the offender as participant by doing what is necessary to explore and capture data with integrity. It is a careful, respectful endeavour of empathetically capturing the essence of often susceptible data of profound human experiences. Together the participant and the researcher discover and uncover meanings of the lived experiences and how the offenders ultimately (re)construct God in the sense-making of their world (Josselson \& Lieblich 2003:260; Josselson 2007:539). 


\section{Voices and themes Images of God: Binary and dialogical}

In this study, the dual role of researcher and participant involves a process whereby both parties become subjects of religious discourse (Scotland 2012:12). Discourse refers to a belief, a narrative or - as in this study - participants' own stories of their religious, spiritual truth (Landman 2009:1). Parties are both parts of the research process of discovering, rediscovering and reconstructing reality. Participants' stories become the text from which the researcher organises the narratives in terms of meanings, truth and (re)constructs realities, as experienced and shared by the participants (Terre Blanche et al. 2012:333). Discourses (Mogashoa 2014:105) are expressed through language, whereby participants construct meaning, understanding and knowledge of their concept and image of God as experienced in their lives.

During this study, these discourses were communicated through one-on-one interviews, group discussions, nonverbal cues and expression of images and symbols. These engagements provided the researchers with the opportunity to investigate the meanings constructed by participants through their religious language, personal orientation, spiritual journey and culture (Shaw \& Bailey 2009:413). Coupled with this in the interpretation of their (re) construction of God-images, due consideration was given to their current context, social and individual setting.

In analysing the discourse of their incarceration, their longterm life sentence was viewed as a journey of suffering (Van der Ven 1998:211). In this study, the researchers were interested in how the participants' (re)construction of God assists in dealing with this suffering. Of further interest is how their articulation of these concepts or images of God underlies this discourse (Landman 2009:106). Given the diversity of the participants' religious orientations in the discourses and narratives, due consideration was given to the features of (black) African religion and spirituality, and how participants construct images of God through their lived lives. The findings during this study showed that African spirituality, its images, concepts or experiences are not exclusive to Africans, neither do all Africans share the same religion or spirituality (Kasambala 2005:300). Nine themes were identified, which were revealed as binary or dialogical relationships between God and interviewe. Binary discourses of concepts or images of God transpire in a power relationship of God versus the powerless human, identified as (1) the apathetic God, (2) the retributive God, (3) the controlling God and discourse of dialogical relationship with God as (4) the therapeutic God, (5) the compassionate God, (6) God, the innocent sufferer, (7) God defined by culture, (8) God the Great Ancestor and Divine Spirit and (9) the God with whom a mystical union is formed.

In constructing and often deconstructing their God concepts and images, the participant and the researcher are moved from the abstract use of language to experiencing and seeing the actual words as giving meaning to their context (Mogashoa 2014:104). These constructions were illustrated through the stories and words of participants as quoted below.

\section{Images of God based on the binary between the divine and human}

The apathetic God remains unmoved by suffering: Conceptualising this discourse closely relates to the pathology of pathos referring to a dynamic and often challenging relationship between God and human (Moltmann 1974:12). As suffering becomes overwhelming, individuals relate differently towards such experiences, and it is in such states of suffering that the individual starts questioning the purpose and meaning thereof, relating to their own God-images (Counted 2015:8). In states of anxiety and emotional suffering, people can become begrudged and filled with anger. A person can adopt some anxiety attachment association with God, and often experience life as having no meaning, hopeless, futile and without any future (Counted 2015:8). This attachment involves not a mere passive affection, but more an attitude of apathy, a God who remains unmoved by our suffering (Solivan 1998:48-49) as echoed by the participants:

'I do not understand why God has sent me here, in this manner and so long. I do a lot of Bible study. But I struggle.' (P14)

'Why couldn't I be sent away to another land like in Bible times?' (P28)

'Why put Abraham through that mental suffering? To sacrifice your only child? Just for Abraham to prove his faith? To please God? What does God expect? Does God not care about my suffering?' (P13)

'Why for example Cain and Abel, why Abel wasn't sent to prison?' (P28)

These questions often indicate that the interviewee is experiencing a crisis with God, feeling insecure, isolated and detached from God (Counted 2015). It also links to the traditional theological question of whether God is indeed behind the suffering, and what is the reason and why did he allow this to happen (Louw 2011). In the sufferer's experience of insecurity and feeling lonely in his suffering, God's image is then reconstructed as a mere observer from afar. God is thereby experienced as apathetic, and often confusing, by neither being the creator of suffering nor the one who allows suffering (Van der Ven 1998:212). The participants expressed how they viewed God as unapproachable, distant and immune to their suffering (Counted 2005:10):

'Where was God that day?' (P14)

'Even if the bad things are coming from humankind, man's inner desires, then it is still in the final instance it should be related to something external, if you think like Christians, it should still be God because you can't just say that one thing is coming from God and the other thing is purely human, it's not coming from God.' (P29)

'God need to fix his mistake and change me.' (P13) 
The apathetic God does not necessarily mean being emotionless, but participants construct this distant image to what makes sense to them. In this deconstruction, participants apply similar 'intellect and will' (Moltmann 1974:11) that the apathetic God also possess:

'All that matters are salvation, and God is ... an obstacle race with traps for the intellects.' (P13)

'One can ... deconstruct the Bible, but God still exists.' (P15)

'Does God plan suffering? If so, does God have free will to do so or later change his mind?'

'He was there, but I did not allow him in my life.' (P14)

'Everything is coming from God, but the problem is his creation, it's not like him. All the bad is coming from his creation, not from him.' (P4)

Participants' outcries portray not only anger and disappointment, but also a desire for an attachment with God to engage in finding answers (Counted 2015). Insecurities and uncertainties often lead to a journey of self-reflection and a re-valuation and what they, while incarcerated, need from their relationship with God (Counted 2015).

The retributive God permits suffering as punishment for sin: From the earliest times pain and suffering, as punishment, played a dominant role in many forms of religions, denomination or spiritual belief systems and were ascribed to various higher beings, powers or spirits (Anderson 2013:17). A retributive God, as theorised by Van der Ven (1998:212), permits suffering as punishment for sin. As people, we are responsible for our suffering by our sinful deeds, and a just and omnipotent God administers or allows retribution for our crimes (Kangwa 2016:6-9). Participants shared the following on their experiences in this regard:

'Not a punishment, but as a wake-up call. God had to put a stop to what I was doing. I had to stop.' (P11)

'He does live inside of me, to follow his ways is a way to him and his compassion and kindness, full of love and he does not [allow] the unjust go free.' (P29)

'He created everything, as I said predestination, he knew that we're gonna do bad, we cannot be like him, we cannot be perfect.' (P4)

Through their narratives, participants recognised the reality of 'good and evil', and that people are mostly responsible for their own or other's suffering (Adamo 2011:4). In an African context, Adamo (2011:4) explains that sinful acts are often perceived as caused by evil spirits, witches and as the wrath of the ancestors. God is, however, also acknowledged as the One who punishes sins and disciplines his people (Adamo 2011:4):

'God does not cause you to go to prison. Satan does not cause you to go to prison, your sins do.' (P10)

'God is not therapeutic, he is just, loving, caring, but his wrath does come on the sinful and wicked.' (P6)

'The opposite of God is not Satan but your sins.' (P10)
'I can't say my evil works put me here. But the Bible says the steps of the men are guided by God, how can the man understand his own ways.' (P9)

Through this reconstruction more male offenders as participants in this study experience God as being concerned with all people and their well-being, as that God is distant or withdrawn (Adamo 2011:5; Han \& Beyers 2017:22). Born in sin, all people will be punished, but also saved by his grace (Adamo 2011:5) as reflected in the following:

'He will take you to prison to test you, it is written in the Bible. Even God he can allow that to happen so that he can align you.' (P10)

'Yes, sins are being punished, and on that day of reckoning this will surely happen, but to blame God for what happened in my life without taking responsibility for those actions, decisions cannot happen.' (P30)

'Here I ran into that brick wall, and now I realise that now the One who created me, the One who died for me has got my attention full-time.' (P7)

'So, there was a time whereby I ask myself that no maybe the God that we [are] serving, our own God is somewhere, you know, he is missing. We have forsaken him. So, I wanted to go back to that God, the one that created me.' (P5)

In their search for reason and the meaning of their suffering, these participants' image of God as the supreme Creator is reconstructed as God the Redeemer (Han \& Beyers 2017:22), the One who did not forsake them, but often the one they turned away from.

The planning God permits or plans suffering within the greater context of time, the meaning of which the sufferer will only understand later: The concept of suffering as undisclosed divine intervention has for ages formed part of various religions, whether it encompassed a belief in supernatural powers that regulate all living organisms to that of strictly structured religions such as Christianity, Judaism and Islam (Anderson 2013:17). Suffering is placed in a bigger frame of events in terms of time and space and only at a later stage will God reveal the meaning of a person's suffering (Van der Ven 1998:213) as voiced by the participants:

'Bad is allowed by God to achieve certain goals.' (P30)

'I hoped that maybe God's plan for or me is to do something for him instead of going to prison.' (P14)

'God plans suffering. God is in us all.' (P2)

'I view sin as a western propaganda to instil fear ... my God is a loving God and has created everything right here on earth for me.' (P5)

'Where God leads you that is where he wants you.' (P16)

'Yahweh God had bigger plans for me.' (P16)

Some religions follow the conviction that God causes suffering for people to learn from, to find purpose in pain and should be embraced (Anderson 2013:17). God's omnipresence in 
the formation of our lives is confirmed through people's conscience that acts as God's voice to one's soul during times of punishment (Beeke \& Jones 2012:14). The participants' experiences of these concepts were described as follows:

'Some of this stuff started coming back stuff like Psalms 23 and some stuff in the New Testament, and one day I just started acknowledging that I am here because of myself trying to do everything myself and not letting God direct me ... then I just completely changed ... changed entirely.' (P6)

'God does not allow wickedness or bad things to happen to any individual ... He allows it, ... you need to learn from your experience.' (P30)

'God can do anything. God fails to fail. Only God knows I am innocent. He sent me to prison not as punishment but as a calling.' (P19)

'To leave it in God's hand.' (P7)

'You see ... God wants you to learn to see how much he loves us. And if we disobey him, he doesn't ... because he knows that the judgement is there at the end of the day.' (P21)

The different circumstances in a person's everyday lives are also seen as some form of divine intervention and geared towards salvation and not to destroy or destruct the person (Beeke \& Jones 2012:15). These sentiments, as articulated by the participants, illustrate the meaning of their suffering and how they (re)construct God's bigger plan to save them:

'But on top of that, God was having a purpose of my life. That's why he didn't let me die outside.' (P21)

'It says in the steps of the men are guided by God, how can the man understand his own ways. 'You see, so God is giving us a chance to have right and happy way, that's why we didn't die at the early stage.' (P9)

'Why does God do this to me while I am innocent, and yet God keeps me healthy in here and keeps me from committing suicide?' (P20)

God plans and initiates new paths for people, who within their incarcerated circumstances are often unable to see these alternative ways themselves (Grimsrud \& Zehr 2002:265), as narrated:

'I never realised the value of what God gave me.' (P14)

'That's why now I think sometimes God has got a plan, because he can see there is this person, he can ... maybe I must take him and put him somewhere, maybe he will focus.' (P7)

'Maybe I wasn't trusting God outside, now I do trust God. I do trust God for being in control of my whole life and I know he has got a purpose for everything that happens in my life.' (P11)

The images of God by these representations demonstrate how the men acknowledge him as being sovereign (Talbot 2006:72), and in control both during adversity and good times. Reasons why he allowed people to do wrong and why evil was done upon them will only be revealed later. For now, the offenders find some acceptance of their punishment and will endure the suffering, as a reward, of which the meaning and understanding will be learnt later (Talbot 2006:72).

The therapeutic God purifies people through suffering for them to realise their true humanity: The therapeutic God, as explained by Van der Ven (1998:213), occupies a kind of middle ground between the retributive, distant God and a nearer God. Humans establish a closer relationship with God, believing that God purifies people through suffering in order for them to realise their true humanity (Van der Ven 1998:213). God despises sinful acts and is concerned about how it affects human beings, and also those guilty of such actions. Therefore, God engages with people with love and justice to heal and restore all people (Grimsrud \& Zehr 2002:266), as portrayed through the voices of participants as well:

'God said he will restore me.' (P16)

'Who I was and who I am now is a miracle if you compare the two people.' (P7)

'Now I go where God wants me to go. God makes me peaceful and healthy. He gives me spiritual strength and helps me to carry pain without medication.' (P21)

'Yes I did many wrong things in my life, ... but you know God is always gracious and he has shown me that, even though I'm not guilty of what I'm incarcerated for, that was his clarion call to me to wake up, open my eyes and open my ears because before he tried to get my attention and I just ignored him. So, I'm, this ten year was a blessing second to none, opened my eyes for so many things, that I never would have think of, if left to myself.' (P3)

'That means the second chance that I've got, that God has given me, it was definitely a blessing for me. It was a blessing for those who have seen me walking that path. When I go back, they will say your friends have passed away, what went wrong, how did you survive?' (P25)

To be incarcerated serves as a means of God to heal and restore broken souls and relationships (Grimsrud \& Zehr 2002:253). God's concern with people also involves the healing of their conscience (Beeke \& Jones 2012:11; Grimsrud \& Zehr 2002:264). Those who wish to be purified and grow spirituality will find meaning in their suffering (Rouzati 2018:9). Representations of these God-images were articulated as follows:

'I am totally different ... than the way I was before. Because I think that's why I say sometimes God made me do things in his plannings, because even the way I was thinking and doing things it's not the same. Now because I can see now, I changed, and I think, I don't just do things now.' (P11)

'I have grown spiritually here. God has healed me emotionally. I am now his prophet.' (P25)

'Ja there I should be dead! Ja, being here is a blessing because I am saved now, and I know the Lord now. And I had found the purpose of God about my life, so it is a blessing to me.' (P9)

In their spiritual journey, some of the men incarcerated have as an aim to be healed and cleansed. It is within this search for the meaning of their lives that they discover hidden messages such as that life consists of good and evil (Rouzati 2018:13). It is also a journey of tests and trials and the discovery that this is also a process of choices. Whether it is in search of God, spirituality or a new reality, as voiced by the participants:

'Then comes the test of your faith ... it is as if I've been robbed from it.' (P14) 
'You see transforming is not a thing of one day, to change it is a process, and you must be patient with people as God was patient with me.' (P9)

'Initially as Christian I believed God punished me, because he loved me. Since I left Christianity, I believe that I should be accountable for my actions.' (P12)

\section{Images of God based on the dialogue between divine and human}

The compassionate God is present with those who suffer (co-travellers): God is compassionate. God is an all-present co-traveller with those who suffer. God heals, comforts and supports the sufferer (Van der Ven 1998:213). God proclaims forgiveness and hope by establishing close relationships with the sufferer, victims, the sinner and the outcast (Moltmann 1974:7). In our experiences with God through these images, humans begin to relate and form a concept of a living and merciful God (Counted 2015:11) as represented by the participants below:

\section{'The chains put by Satan, God can break it.' (P5)}

'To me finding God again ... and for me finding out that he never left me, but I left him. (P14)

'I don't actually have to go and defend myself to them. If they don't want to accept me, they don't want to accept me. The nice thing about it is ... I cannot go lower than where I am now ... in anyone's eyes ... especially people's eyes. So, if the church shuns me ... I know that God has me and that's good enough for me.' (P3)

God-images and metaphors of compassion, as described by Kasambala (2005:319), closely relate to African images of God as a mother, shepherd or companion, and friend. The image of a compassionate God is also portrayed as a shepherd, guarding and caring for God's flock (Kasambala 2005:320). God's kindness and forgiveness are unconditional. His omnipresent compassion and love take 'precedence over wrath' (Grimsurd \& Zehr 2002:262). Some participants also share these constructs:

'I said now why did I survive? I will never forget his words, the Lord has a plan for your life and to be honest with you, when I was, the day I was actually sentenced, it didn't make any sense to me and I felt abandoned but he's so gracious, he said no, you know, you look back and you see but there is only one set of footprints in the sand and then he reminds you that when times were the toughest, that's why you don't see two rows of footprints because that's the time I was carrying you.' (P3)

An image of God as mother (Kasambala 2005:319), the one who knew you first before you were born, universally relates to feeling cared for and nurtured, and as a child when in pain, returning to the love and security of a mother, as voiced by some participants:

'My mother was barren. Like the barren women in the Bible she eventually gave birth to a giant. That is my journey with God.' (P2)

'I moved away from Christianity, became a Buddhist and then an atheist. I am returning to God now, but not the God of the Old Testament. God is a presence. God is love and care.' (P13)

'Here it's a spiritual journey that I had to take at some point in life because as they say, as the Bible says that God knew you before you were born, he called you by name while you're still inside your mom's womb.' (P5)

Constructing God as a friend refers to the one you can trust and confide in, who is always there for support. Mbiti (cited in Kasambala 2005:320) illuminates this further as a close relationship between friends, with whom one can talk openly with no judgement - a relationship shared by some participants:

'I can only trust in what God has planned for me. And whatever God has planned for me, I'm happy. He has a plan with me, but I do not know what it is ... all I know is that God is just but merciful.' (P7)

'God is not a concept. It is important to know God's personal name to have a personal relationship with him.' (P29)

'I talk to God a lot. God is a God of love. God talks back through Bible messages. I believe in a compassionate God who has given me a free will.' (P1)

'To love God and you will have faith in him and you will have hope in him and trust in him also.' (P9)

God-images (re)constructed as a compassionate companion closely reflect on the theory of need for attachment and closeness to others as typical of mother-child, friendconfidant-companion relationships (Counted 2015:4). It can represent itself in various forms, a yearning or reconstruction of what was, or construction of what they desire. Constructions of a God of compassion and mercy display how these men experience a reciprocal desire to form meaningful relationships and are open to accepting God's divine interventions (Louw 2011:10; Moltmann 1974:12).

The suffering God becomes an example for those suffering innocently to identify with other sufferers (co-sufferers): God, the innocent sufferer through God's Son, becomes an example for those suffering to identify with other sufferers. As co-sufferer God relates to the sufferer, also as someone who will faithfully care for his followers (Landman 2009:107; Van der Ven 1998:214). This notion of a changing God from apathy to sympathy is expressed by the participants' (re) construction of their God images as follows:

'I'm totally dependent on God. His son died for me and rose from the dead.' (P9)

'Especially when I read through the New Testament ... I can see more in the Apostles of Jesus, how lovable he was when he died for others ... it just completely changed it's no longer a God that you have to be scared of.' (P7)

'He says he did a sacrifice once and for all that is Jesus Christ. So, these things of gangsterism are the sacrificing of the demons, not for God.' (P8)

'I don't want to hurt him who has given his life for me, so now I'm trying by all my human weakness and flesh to obey what he says.' (P3)

In reaction to extreme offences against human nature, society and its laws, and God's laws, Grimsrud and Zehr (2002:257) extrapolate that God can only relate to people by moving 
beyond mere compassion, sympathy and godliness. There is an urgency to balance out the unrighteousness of humankind with God's righteousness, only achieved by the death of his own Son and sharing the journey of suffering. These images of God as experienced by participants are as follows:

'I'm into a faith, a living faith because I know my creator lives and I know as he sent his Son for to die for my sins and for the sins of the world that he will return.' (P3)

'Sometimes suffering can be an example to those who are suffering in order for them to have hope, ... and find solace from so many people, in the Bible or religious books who were once imprisoned.' (P5)

'I don't try to win his favour by doing anything, but I am showing gratitude for what he has already done on my behalf.' (P3)

God allowed his son to be humiliated, who took upon himself the suffering of inhumanity, and who died on the Godabandoned cross (Moltmann 1974:7). The message was to break down the misconception of God and human in opposing worlds of me-and-them, innocent-and-guilty, but to acknowledge shared suffering (Grimsrud \& Zehr 2002:272). As described by Moltmann (1974:9), it is more than just a reminder of Jesus' suffering, but more so an act of deliverance and hope, beyond the cross as articulated by some participants:

'Jesus changed everything when he became one of us, lived amongst us, when he died on the cross for my sins ... for God can be anything but compassionate, even through punishment.' (P8)

'When we suffer, we only follow his example ... with the concept of self-less service to others.' (P17)

'My hope is Jesus Christ. When I leave this earth one day I will be resurrected as God says.' (P9)

'Which makes God in a sense your own personal God, ... your anthropomorphosised idea of how the world should be.' (P12)

It is almost inevitable that the question of the innocence of God is raised. Who is behind our suffering, if God is indeed the creator thereof, why does he allow it? (Louw 2011:10), as echoed by a participant in this study:

'As innocent sufferer ... he created the world and suffering ... so if he created suffering, is he really an innocent sufferer?' (P11)

In this regard, one can only attempt to make sense of this by referring to the supposition of Moltmann (1974:9), whereby God acknowledges that he causes suffering and he can only create hope by the 'destruction of the apathetic' by defeat on the cross. It is only through the suffering God, sacrificing his own Son and giving himself as 'ransom' (Moltmann 1974:13) that God attempts for humankind to accept his act of deliverance and accountability.

God who identifies with culture: According to Kalilombe (1999:220), African spirituality can be described as individuals' attitudes, beliefs, culture or customs in their sense-making of their religious realities in terms of God, the spirits, visible and invisible powers around them. The issue of culture often poses generalisations such as that the religion practised is an indication of the culture an individual belongs to or religion serves as an indication of a person's cultural identity (Beyers 2017:1).

Some examples of the God-image, in terms of cultural or ethnical concepts, participants identify with are:

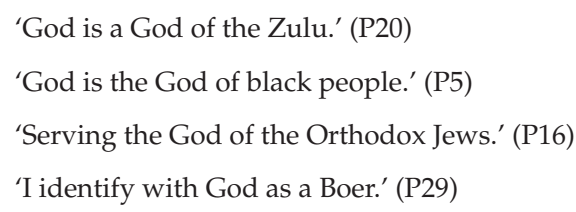

Even though any dialogue on religion and culture is almost inseparable, it is cautioned not to make any generalisation, because Islam, for example, is a religion and cannot be regarded as a culture (Beyers 2017:1).

In addition to God-images illuminated by Kasambala (2005:318-320), such as shepherd, mother and fiend, we can further include the construction of God as father. The image of a father as a protector is called upon in times of despair and adversity (Kasambala 2005:319). Pleads for the protection of family units often strongly relate to the African culture, but not limited to it. In the context of being incarcerated and feeling helpless, this construction of God the Protector carries a significant message:

'I had to accept that I could not protect my wife and children anymore and I had to get someone else to protect them and the only one left was God.' (P1)

The image of God as father is also often experienced as a stern father figure, who controls by rules and laws as the law of God would keep one on track (Kasambala 2005:319), as expressed by the following participants:

'My relationship with God is this, I follow his loving law, I am a servant of God.' (P18)

'I grew up, not knowing that God first God is the God of love, because of all these rules and regulations if you don't do this, ... you know ... just be careful.' (P28)

'God is testing his own through suffering - to see if they will with undivided heart maintain their reliance on and trust in him.' (P30)

Some literature explains how African religion and tradition emphasises that God has absolute power over all and is the sustainer of the universe and everything in it (Lugira 2009:40). Some of the images portrayed God as a warrior and stronghold, particularly concerning the strict dogma, rules and law of the Old Testament:

'I belong to the Church of God. I believe in the God of the Old Testament. I do not understand why I must pray to God through Jesus Christ.' (P11)

'I should go for the God of the Orthodox Jews. I keep the Torah, both the written and the oral Torah.' (P16)

'I restored my relationship with God by keeping his laws.' (P10) 
'I've found that I have drawn much closer to my Creator, to such an extent that a revelation just popped out of scripture for me like that and I started looking at my Hebrew roots.' (P3)

Religion for some remains a form of cultural, communal expression (Beyers 2017:1) using symbols, ceremonial events and rituals (Kasambala 2005:314). In African religion, the emphasis is placed on relationship that traditionally is not an individual endeavour but found all around in the life of the community (Mbiti 1989:2). One cannot merely be separated from those culturally religious embedded practices because being human means sharing community beliefs, practices and ceremonies. It is, however, evident from this study that participants shared these beliefs, images or constructs irrespective of their culture, race or religious beliefs:

'Then its PaschaMatsa, Feast of Our Dead, then it's Shavuot Pentecost where the outpouring of the spirit was and when Yahweh gave the Torah to Moshe on Mount Sinai.' (P3)

'It's part of the church rituals. That's part of the church ritual, so ja. Even here we do Nkuku.' (P5)

Ceremonial events and rituals are universal and not only part of the African religious culture. A common trait in these Godimages is the message of interrelationships and communality, influenced by the role of religion in their culture (Kasambala 2005:320).

God the great ancestor and divine spirit: During this study, many diverse characteristics of African spirituality were articulated by participants in their portrayal of their images of God. One such trait is the hierarchy in which God is viewed, described by Kasambala (2005:306) as 'Supreme Being (Umkulunkulu), the Creator (Mulengi), the Sustainer of the universe (Musungililiwavyose)'. Here Magesa (1997:n.p.) expands on this by describing God as the Great Ancestor, the Giver of Life and the Founder behind everything. The participants represented the following constructed images of God:

'They'll tell you that don't forget your ancestors, don't forget your roots. This is a church of the ancestors, even in the morning when I go to church, I have to invite my ancestors to go with me there.' (P5)

'Before we start any prayer for the day or anything we have to try and talk out a way of dealing with the other people's spirit ... when you sing this song all the ancestors that have to be there, they will come and be with us.' (P30)

'There are three witnesses: it's the Word, it's the Father and it's the Spirit. So, the Holy Spirit will never contradict the Word.' (P4)

'Allah is God and Muhamad is my ancestor.' (P6)

The God with whom a mystical union is formed: In suffering, humans surrender to God in their desire to form a mystical union with God. Their search for the divine does not stand in a punisher-punished relationship with God anymore (Landman 2009:107-107; Van der Ven 1998:214). God is experienced in our entire existence and everyday matters, human, non-humans and nature. His spirit is always active in our existence and everything that surrounds us (Van der Ven 1998:17).
A mystical union refers to a heightened holy state, experienced as a real or symbolic union with God. These mystical relations are characterised by hidden, mysterious meanings and messages (Levasseur 2011:3). Such union, similarly, represented in terms of African cosmology, refers to how cosmic forces consist of visible and invisible spirits (Van der Merwe et al. 2010:3) that form part of individuals' lives.

Full union with God: Human suffering does not necessarily lead to forming a union with God. For a mystical union with God, a person must take up his or her cross and follow Christ (Urbaniak 2014:8). To achieve full union with God is not a reward for suffering, but rather as a result of the meaning found in life through it and the close relationship established with God. Bailey (cited in Urbaniak 2014:8) refers to 'visiobeatifica' a very close God-human relationship, whereby God directly communicates with a person. This almost full union with God, as experienced by some participants, is described as follows:

'There is no difference between me and God ... a person can become like God if you live an enlightened life.' (P26)

'I asked to escape, and God helped me.' (P6)

'A personal God, which is the person himself. God is the mirror image of your own personality.' (P28)

'He is an omnipotent God and he lives in me. Me and God are one.' (P24)

Kasambala (2005:308) elaborates on this aspect of spiritual mysticism as seeing the soul of humankind interconnected with the universe, cosmos and nature. Union with God in a divine invisible world is constructed where everyday lives are ordered and no occurrence is without cause, explanation or meaning (Kasambala 2005:312). Participants voiced similar constructions in this regard:

'God is the metaphysical aspect of reality. Nature is the physical aspect of reality. I believe in Monism ... unity of physical and metaphysical.' (P26)

'A person can become like God if you live an enlightened life.' (P26)

'God and the cosmos are actually the two sides of the same coin. The one is the soul or vibrational or consciousness aspect, and the other one is the material aspect of reality.' (P26)

'I speak to God in tongues one hour every day.' (P24)

'If I want to pray in spirit now, I can pray in the spirit.' (P4)

There is also a common notion to describe their union with God as very intimate. In this relationship a person is described as being the 'Bride' and God as Husband, 'Bridegroom' or 'Beloved' (Spitzer 2016:7). Within their particular religious framework, participants expressed this construction of their bond with God as follows:

'So, there are several other places in a Bible where specifically he is referred to a marriage. Not in that specific word, but where our Heavenly Father refers to that he is our husband and our maker.' (P29)

'To me God is the significant other.' (P15) 
This bond exemplifies the ultimate intimate, loving relationship with God such as in a marriage. The desire for an attachment and meaningful relationship with others includes relationships with amongst loved ones and partners as significant others (Baumeister \& Leary 1995:497; Counted 2015:4). Such relationships are not necessarily on an individual level, but often more representative of the transformation of a nation's soul to an ultimate loving relationship with God and others (Spitzer 2016:3).

Partial union with God: In a person's search for spiritual healing, irrespective of the religion or belief system, it remains a journey to seek unity with God or a god to sacrifice all of oneself. The belief remains that it is indeed possible to achieve full unity - a strive for life-giving divine engagement:

'I am a man of God.' (P9)

'People say I must not use religion as a crutch. But I am not into religion, I am into faith, I am into God.' (P3)

'God is life. If I part from him, I part from life.' (P24)

'And the reason why I got involved with Buddhism was because it taught me about suffering ... don't hurt any living being, you know Karma.' (P13)

God conveys leadership and the sufferer shares leadership with God: The sufferer's search of this mystical union often takes on a very personal form. In these cases, characteristics that transcend the ordinary are proclaimed more towards Godly attributes (Levasseur 2011:2) as described by some participants:

'God has made me a prophet and a healer. But I remain his servant.' (P8)

'I am a prophet and God talks directly through me.' (P17)

'I am God.' (P5)

These three (re)constructions of a union are referred to by Astell (2005:389) as 'image-language' whereby participants articulate their experiences as real and not merely in symbolic terms but a rational expression of their truth (Levasseur 2011:3). These voices represent their respective journeys, whether biblical, spiritual, religious or non-religious to assist in their search for meaning in their suffering and purpose that transcends words.

\section{Conclusion}

The aim of this article is, firstly, to describe and thematise the images of God held by 30 men who were serving long-term sentences in Zonderwater; secondly, to indicate how these images have changed or hardened during incarceration; and, finally, to relate how the formation of God images has led to meaning in the lives of the incarcerated.

\section{Types of God images found amongst the incarcerated}

Amongst the research population, preference is not given to images of God as absent from or punishing the incarcerated. They prefer to think of God as allowing their incarceration because of the therapeutic God engaging them into a larger plan of healing to which they as incarcerated will make a substantial contribution. While this expectation is based on binary views of God as 'the Other' who decides - albeit benevolently - on the fate of humans, a substantial number of participants shunned this view of God as being transcendental in favour of an image of an immanent God that is travelling with the incarcerated in his or her suffering, even becoming one with him. In this God is believed to be culturally sensitive and to identify with the culture of the incarcerated sufferer, whether he or she is black or white.

\section{God images changing and hardening during incarceration}

From the narratives of the interviewees, it becomes clear that major shifts occurred in the ways they experience God since they have been incarcerated. Those who view their incarceration as politically manipulated - white and black hardened their pre-incarcerated views of God as the One who has a plan with their suffering, who favours their culture and plans their liberation. Others, who by their own testimony led a lawless life before incarceration, see God as the lawgiver who rewards good behaviour. These men return to the self-imposed laws of their religion to rediscover themselves as law-abiding citizens worthy of release from incarceration. Another category of participants completely and consciously abandon their learned pietistic or political views of God to turn to atheism or esoteric forms of eastern religions.

\section{God images giving meaning during incarceration}

The men find meaning in their God images by experiencing God as planning their healing, restoration or release. Some of the men find meaning in God becoming one with them to bestow them with godlike features, which distinguish them from ordinary criminals who deserve their sentences. However, most of the participants accept their punishment but find meaning in God's envisaged healing engagement with them and the sharing of religious laws and practices with other inmates.

The researchers are enriched and enlightened by the monthly engagement with the participants, their honesty and their willingness to share their journey with God with the researchers who can only be identified now as co-researchers.

\section{Acknowledgements}

The process of applying for ethical clearance from the Department of Correctional Services was driven by Mbongiseni Mdakane, who originally conceptualised the project. 


\section{Competing interests}

The authors declare that they have no financial or personal relationship(s) that may have inappropriately influenced them in writing this article.

\section{Author(s) contributions}

The authors and researchers equally contributed to the writing of this article.

\section{Ethical consideration}

Ethical clearance to conduct this study was obtained from both Unisa and the Department of Correctional Services.

\section{Funding information}

This research received no specific grant from any funding agency in the public, commercial or not-for-profit sectors.

\section{Data availability statement}

This research received no specific grant from any funding agency in the public, commercial or not-for-profit sectors.

\section{Disclaimer}

The views and opinions expressed in this article are those of the authors and do not necessarily reflect the official policy or position of any affiliated agency of the authors.

\section{References}

Adamo, D.T., 2011, 'Christianity and the African traditional religion(s): The postcolonia round of engagement', Verbum et Ecclesia 32(1),1-10. https://doi.org/10.4102/ ve.v32i1.285

Anderson, R.E., 2013, Human suffering and quality of life. Conceptualizing stories and statistics, Springer, New York.

Astell, A., 2005, 'Biblical images of God and the reader's "I" as Imago Dei the contribution of Edith Stein', Interpretation 59(4), 382-391. https://doi. org/10.1177/002096430505900405

Baumeister, R.F.\& Leary, M.R., 1995, 'The need to belong: Desire for interpersonal attachments as a fundamental human motivation', Psychological Bulletin 117(3), 497-529. https://doi.org/10.1037/0033-2909.117.3.497

Beeke, J.R. \& Jones, M., 2012, A Puritan theology. Doctrine for life, Reformation Heritage Books, MI, viewed 28 March 2019, from http://www.pcabookstore.com/ samples/12682.pdf.

Beyers, J., 2017, 'Religion and culture: Revisiting a close relative', HTS Teologiese Studies/Theological Studies 73(1),1-9. https://doi.org/10.4102/hts.v73i1.3864

Clandinin, D.J., 2006, 'Narrative inquiry: A methodology for studying lived experience', Research Studies in Music Education 27(1), 44-54. https://doi.org/10.1177/1321 103X060270010301

Clandinin, D.J., 2007, Handbook of narrative inquiry: Mapping a methodology, Sage London.

Clandinin, J., Caine, V., Estefan, A., Huber, J, Murphy, M.S. \& Steeves, P., 2015, 'Places of practice: Learning to think narratively', Narrative Works. Issues, investigations, \& Interventions 5(1), 22-39.

Connelly, F.M. \& Clandinin, D.J., 1990, 'Stories of experience and narrative inquiry', Educational Researcher 19(5), 2-14, viewed 6 October 2018, from https:// journals.sagepub.com/doi/10.3102/0013189X019005002

Connelly, F.M. \& Clandinin, D.J., 2006, 'Narrative inquiry', in J. Green, G. Camilli \& P. Elmore (eds.), Handbook of complementary methods in education research, pp. 477-487, Lawrence Erlbaum, Mahwah, NJ.

Counted, V., 2015, 'Understanding God images and God concepts: Towards pastora hermeneutics of the God attachment experience', Verbum et Ecclesia 6(1), 1-14. https://doi.org/10.4102/ve.v36i1.1389
Geertz, C., 1973, Religion as a cultural system. The interpretation of cultures. Selected Essays, Basic Books, Inc., New York.

Grimsrud, T. \& Zehr, H., 2002, 'Rethinking God, justice, and treatment of offenders', Journal of Offender Rehabilitation 35(3-4), 253-279. https://doi.org/10.1300/ J076v35n03 14

Han, Y.S. \& Beyers, J., 2017, 'A critical evaluation of the understanding of God in J.S. Mbiti's theology', Acta Theologica 37(2), 5-29. https://doi.org/10.18820/23099089/actat. v37i2.2

Josselson, R., 2007, 'The ethical attitude in narrative research principles and practicalities', in D.J. Clandinin (ed.), Handbook of narrative inquiry, pp. 537-566, Sage, Thousand Oaks, CA.

Josselson, R. \& Lieblich, A., 2003, 'A framework for narrative research proposals in psychology', in R. Josselson, A. Lieblich \& D.P. McAdams (eds.), Narrative research proposals, pp. 259-274, American Psychological Association, Washington, DC.

Kalilombe, P.A., 1999, Doing theology at the grassroots. Theological essays from Malawi, Mambo Press, Gweru.

Kangwa, J., 2016, 'The role of the theology of retribution in the growth of PentecostalCharismatic churches in Africa', Verbum et Ecclesia 37(1), 1-9.

Kasambala, A.E., 2005, 'The impact of an African spirituality and cosmology on God images in Africa: A challenge to practical theology and pastoral ministry', International Journal of Practical Theology 9(2), 300-32. https://doi.org/10.1515/ ijpt.2005.9.2.300

Landman, C., 2009, Township spiritualities and counselling, Pretoria Duplicating Company, Pretoria.

Landman, C., Ncongwane, H.J. \& Pieterse, T., 2019, 'Men serving long-term sentences in Zonderwater correctional centre, South Africa: Religious identity and behavioural change', HTS Teologiese Studies/Theological Studies 75(3), 1-11. https://pdfs.semanticscholar.org/e91a/c9fab24d33d75868ebbd737280f5e 53f2441.pdf?_ga=2.150549310.949659907.1571730593-44944713.1557830805.

Levasseur, P.W., 2011, 'The phenomenology of everyday experiences of contemporary mystics in the Jewish traditions of Kabbalah', PhD thesis, Trace: Tennessee Research and Creative Exchange, University of Tennessee. viewed 30 March 2019, from https://trace.tennessee.edu/utk_graddiss/1093.

Louw, D.J., 2011, 'Ta splanchna: A theopaschitic approach to hermeneutics of God's praxis. From zombie categories to passion categories in theory formation for a practical theology of the intestines', HTS Teologiese Studies/Theological Studies 67(3), 1-13. https://doi.org/10.4102/hts.v67i3.1087.

Lugira, M., 2009, World religions. African traditional religion, Chelsea House, New York.

Magesa, L., 1997, African religion: The moral traditions of abundant life, Orbis Books, New York, viewed 27 February 2019, from https://www.amazon.com/ African-Religion-Moral-Traditions-Abundant/dp/1570751056.

Mbiti, J.S., 1989, African religions \& philosophy, Heinemann Educational Publishers, Oxford.

Mogashoa, T., 2014, 'Understanding critical discourse analysis in qualitative research', International Journal of Humanities Social Sciences and Education 1(7) 104-113.

Moltmann, J., 1974, 'The crucified God', Theology Today 31(1), 6-18. https://doi. org/10.1177/004057367403100102

Rouzati, N., 2018, 'Evil and human suffering in Islamic thought-towards a mystical theodicy', Religions 9(47), 1-13. https://doi.org/10.3390/rel9020047

Scotland, J., 2012, 'Exploring the philosophical underpinnings of research: Relating ontology and epistemology to the methodology and methods of the scientific, interpretive, and critical research paradigms, English Language Teaching 5(9), 9-16. https://doi.org/10.5539/elt.v5n9p9

Shaw, S.E. \& Bailey, J., 2009, 'Discourse analysis: What is it and why is it relevant to family practice?', Family Practice 26(5), 413-419. https://doi.org/10.1093/fampra/ cmp038

Solivan, S., 1998, Spirit, pathos and liberation: Toward an Hispanic Pentecostal theology, Sheffield Academic Press.

Spitzer, R.J., 2016, The stages of Christian mysticism: A summary, Magis Center.com [online], Garden Grove, CA, 2019. viewed 21 March 2019, from https://www. magiscenter.com/ the-stages-of-christian-mysticism-a-summary/

Talbot, M.R., 2006, 'All the good that is ours in Christ: Seeing God's gracious hand in the hurts others do to us', in J. Piper \& J. Taylor (eds.), Suffering and sovereignty of God, pp. 31-80, Good News Publishers, Wheaton, IL.

Terre Blanche, M., Durheim, K. \& Painter, D., 2012, Research in practice, 2nd edn., University of Cape Town Press, Cape Town.

Urbaniak, J., 2014, 'Suffering in the mystical traditions of Buddhism and Christianity', HTS Teologiese Studies/Theological Studies 70(1), 1-9. https://doi.org/10.4102/ hts.v70i1.2117

Van der Merwe, E.K., Van Eeden, C. \& Van Deventer, H.J.M., 2010, 'A psychological perspective on god-belief as a source of well-being and meaning', HTS Teologiese Studies/Theological Studies 66(1), 1-10. https://doi.org/10.4102/ hts.v66i1.332

Van der Ven, J.A., 1998, God reinvented? A theological search in texts and tables, Brill, Leiden.

Vergote, A., 1996, Religion, belief and unbelief: A psychological study, Leuven University Press, Amsterdam. 